\title{
The Perception of Marketing Mix of TICA by Convention Providers in Bangkok
}

\author{
Qiu liang
}

\author{
Sichuan College of Architectural Technology Si chuan ， De yang 618000
}

Key words: Convention; TICA; Marketing mix

\begin{abstract}
Convention is one of the most important sectors within the business travel and also one of the fastest growing segments in world tourism. Thailand is recognized as one of the region's finest and best-equipped venues in Southeast Asia. This research is aimed to study the perception of marketing mix of TICA (Thailand Incentive and Convention Association) by the convention providers in Bangkok.

This research studies the perception of convention providers towards TICA in marketing mix, which are product, price, promotion and distribution. Three hundred and eighty four questionnaires were distributed to the staff of convention hotels and convention centers in Bangkok. The respondents were asked to mark the TICA in eight aspects of marketing mix separately.

From data analysis, the researcher found that there is a significant difference between convention hotels and convention centers in their perception of four aspects of marketing mix of the TICA in Bangkok.
\end{abstract}

\section{Introduction}

\subsection{Statement of the problem}

According to Abbey and Link (1994), the convention and meetings business is an element of the tourism industry that is one of the highest growth-oriented sectors of tourism. The convention business has the potential to bring significant economic and social benefits to every country. Growth in this industry can increase job numbers, foreign exchange earnings, business attractions and investment. Nowadays, the competition of the right for organizing each famous international convention will be generated among ten or more countries or regions. The result will come after drastic competition.

As the competition among destinations to host conventions intensifies, destination managers face numerous marketing challenges in creating positive destination images. Accordingly, the role of a convention and visitor bureau (CVB), the primary destination marketing organization of a destination, has become more important.

The perception of the mix of Thailand CVB by convention provider perspectives such as hotels, convention and exhibition centers can bring information about destination marketing and the role of Thailand CVB.

The study is designed to explore the perception among different types of convention providers towards different destination marketing mix with product, price, place and promotion dimensions performed by convention and visitor bureaus in Bangkok.

\subsection{Introduction of the study}

\section{Overview of Convention and Visitor Bureaus}

According to Morrison, Bruen and Anderson (1998), the first CVB (Convention and Visitor Bureau) started in 1896 in Detroit, Michigan. It can be said that the mission and main task of convention bureaus worldwide is to promote and sell cities. Most CVBs have historically been non-profit associations that promote general business services for the different entities (restaurants, hotels, attractions, etc.) in the surrounding areas. And it has also been responsible for attracting large, small meeting and pleasure travel groups to the local communities (Morrison, et. al 1998). When the convention bureaus are creating a certain image that goes well with how the city is positioned in the global community, they market destinations for upcoming events and congresses. So, CVB is primarily the destination marketing organization which links the different providers 
together to promote and sell the host destination. It plays the central role in marketing for their geographic areas to meeting and convention planners, the travel trade, individuals, and other related groups. The key role of CVB is therefore a leading team for "destination marketing". One of the key organizations which contribute much to the destination marketing of Thailand is the Thailand Incentive and Convention Association.

\section{Thailand Incentive and Convention Association (TICA)}

The Thailand Incentive and Convention Association (TICA) is a non-profit organization established in 1984 jointly by the government (the Tourism Authority of Thailand and Thai Airways International) and the private sector. TICA's function is to aid the growth of Thailand as a preferred destination for meetings, incentives, conventions and exhibitions. (http://www.tica.or.th/)

\section{Research Framework}

\subsection{Conceptual Framework}

This study is about the relationship between the convention providers and the CVBs. Especially the providers' perception toward the marketing mix of CVB in Bangkok. A list of types of convention provider's variables in relation to the dimensions of destination marketing of CVB was studied. This study emphasizes that the types of provider are key indicators of efficiency towards the four marketing mixes of destination marketing.

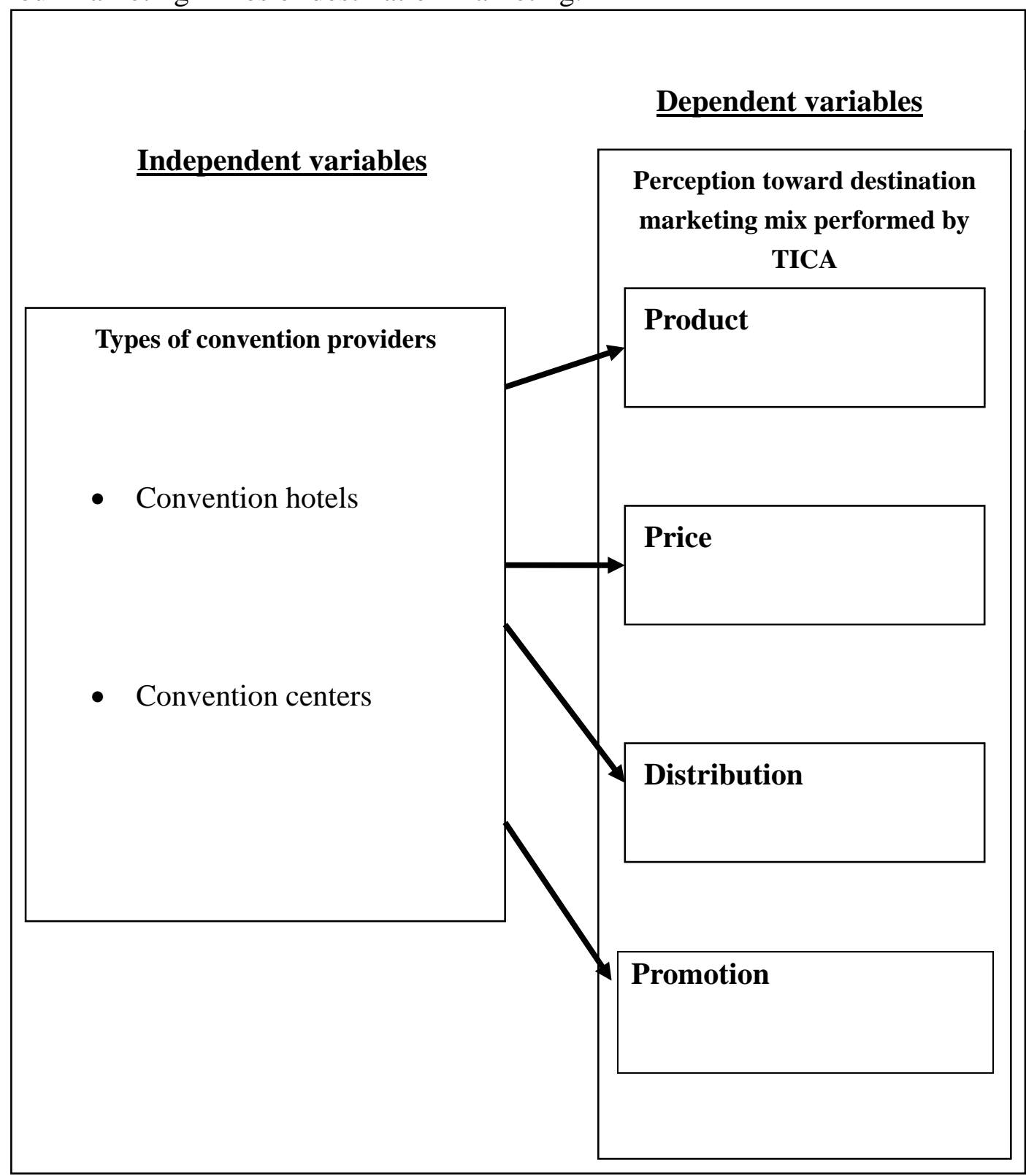

Figure 1 Conceptual Framework 


\subsection{Research Hypotheses}

Based on the above conceptual framework, the following hypotheses are set up to prove the relationship between variables.

\section{Hypothesis}

Ho1

There is no difference between convention hotels and convention centers in their perception of product mix of the TICA in Bangkok.

Ha1 There is a difference between convention hotels and convention centers in their perception of product mix of the TICA in Bangkok.

Ho2 There is no difference between convention hotels and convention centers in their perception of price mix of the TICA in Bangkok.

Ha2 There is a difference between convention hotels and convention centers in their perception of price mix of the TICA in Bangkok.

Ho3 There is no difference between convention hotels and convention centers in their perception of place mix of the TICA in Bangkok.

Ha3 There is a difference between convention hotels and convention centers in their perception of place mix of the TICA in Bangkok.

Ho4 There is no difference between convention hotels and convention centers in their perception of promotion mix of the TICA in Bangkok.

Ha4 There is a difference between convention hotels and convention centers in their

\section{Summary, Conclusion, and Recommendations} perception of promotion mix of the TICA in Bangkok.

\subsection{Summary of findings}

\subsubsection{Summary of convention providers' perception about rankings of marketing mix}

There were 4 rankings of the marketing mix to TICA evaluated by hotels and convention centers separately. These tables indicated the different average scores and the corresponding rankings of the 4 marketing mix based on those scores.

Table 1 The perception of the marketing mix of TICA by hotels and convention centers.

\begin{tabular}{|l|l|l|c|}
\hline \multicolumn{2}{|c|}{ Hotels } & \multicolumn{2}{c|}{ Convention centers } \\
\hline \multicolumn{1}{|c|}{ Marketing mix } & Mean & \multicolumn{1}{c|}{ Marketing mix } & Mean \\
\hline Distribution & 3.5664 & Product & 4.2041 \\
\hline Promotion & 3.2378 & Promotion & 3.8010 \\
\hline Product & 3.1608 & Distribution & 3.4082 \\
\hline Price & 3.1084 & Price & 3.3980 \\
\hline
\end{tabular}

\begin{tabular}{|l|l|l|c|}
\hline \multicolumn{2}{|c|}{ Hotels } & \multicolumn{2}{c|}{ Convention centers } \\
\hline \multicolumn{1}{|c|}{ Marketing mix } & Mean & \multicolumn{1}{c|}{ Marketing mix } & Mean \\
\hline Distribution & 3.5664 & Product knowledge & 4.3980 \\
\hline Collateral material & 3.2797 & Collateral material & 4.3970 \\
\hline Sales promotion & 3.2448 & Product mix & 4.0102 \\
\hline Publicity and PR & 3.2378 & Publicity and PR & 4.0000 \\
\hline Product knowledge & 3.1958 & Distribution & 3.4082 \\
\hline Advertising & 3.1888 & Sales promotion & 3.4075 \\
\hline
\end{tabular}




\begin{tabular}{|l|l|l|l|}
\hline Price & 3.1084 & Advertising & 3.3981 \\
\hline Product mix & 3.0210 & Price & 3.3980 \\
\hline
\end{tabular}

\subsubsection{Summary of hypotheses testing results}

The researcher used Table 3.2 to summarize the results of hypotheses testing. The table confirms all the hypotheses. In this study, there were four hypotheses that were set to test the differences between convention hotels and convention centers in their perception of marketing mix of the TICA in Bangkok. Table 6.1.3 shows hypotheses Ho1, Ho3, Ho5, and Ho7 were rejected.

Table 2 Summary of hypotheses testing results

\begin{tabular}{|l|l|l|l|}
\hline \multicolumn{1}{|c|}{ Hypotheses } & Statistics test & Sig & Results \\
\hline $\begin{array}{l}\text { Ho1: There is no difference between convention } \\
\text { hotels and convention centers in their perception } \\
\text { of product mix of the TICA in Bangkok. }\end{array}$ & $\begin{array}{c}\text { Independent } \\
\text { t-tests }\end{array}$ & 0.000 & Rejected Ho \\
\hline $\begin{array}{l}\text { Ho2: There is no difference between convention } \\
\text { hotels and convention centers in their perception } \\
\text { of price mix of the TICA in Bangkok. }\end{array}$ & $\begin{array}{l}\text { Independent } \\
\text { t-tests }\end{array}$ & 0.016 & Rejected Ho \\
\hline $\begin{array}{l}\text { Ho3: There is no difference between convention } \\
\text { hotels and convention centers in their perception } \\
\text { of place mix of the TICA in Bangkok. }\end{array}$ & $\begin{array}{l}\text { Independent } \\
\text { t-tests }\end{array}$ & 0.061 & Rejected Ho \\
\hline $\begin{array}{l}\text { Ho4: There is no difference between convention } \\
\text { hotels and convention centers in their perception } \\
\text { of promotion mix of the TICA in Bangkok. }\end{array}$ & $\begin{array}{l}\text { Independent } \\
\text { t-tests }\end{array}$ & 0.000 & Rejected Ho \\
\hline
\end{tabular}

3.2 Conclusion - Different convention providers' perception towards the four dimensions of marketing mix in Bangkok

From the whole perspective, the researcher can deduce the conclusions in the following statements:

The four hypotheses Ho were all rejected which means there is significant difference between convention hotels and convention centers in their perception of marketing mix.

According to the means of the 4Ps of the marketing mix, the four means of TICA marked by convention centers were higher than that marked by hotels. It means that convention centers were more satisfied with TICA than with hotels. In other words, convention centers focused on the TICA more than hotels. For the researcher, the reason for that was the business difference. The convention centers attempt to focus on the convention and exhibition markets which, to some degree, relied on the TICA directly. On the other hand, hotels have different target markets. Besides the business travelers, for example, hotels have other target markets such as families and coach groups which have little relation with the convention business.

In product aspect

From the hotel perspective, they rated product knowledge and the development of product mix at a lower degree compared to the convention centers which means they thought that TICA didn't have the MICE product knowledge and TICA didn't develop the product mix for the target market. In contrast with hotels, convention centers rated product knowledge and the development of product mix at a higher degree, which means they thought that TICA had the MICE product knowledge and TICA developed the product mix for the target market. In the researcher's opinion, the reason for the difference is influenced by the different range of the product. In general, hotels have wider range of product than convention centers.

In price aspect

Both hotels and convention centers ranked the price aspect at a very low level. Because TICA is an industrial organization which means it has no right to decide the price. TICA just can control some elements of pricing through regulation, advice and through partnership with the private sector. From this we knew that TICA had little influence on the price to the target market. 


\section{In promotion aspect}

According to the means of promotion aspect of TICA, hotels and convention centers both gave the same ranking of collateral material at a high level, which means the brochures, information handouts, and so on produced by the TICA satisfied both hotels and convention centers. And the hotels and convention centers gave the same perception to publicity and PR at a middle level. There were no differences in collateral material and publicity and PR mix of TICA evaluated by the hotels and convention centers. The most different perception in promotion was sales promotion. Hotels gave a higher mark to the sales promotion of TICA than convention centers. The reason for the difference was that as a marketing tool sales promotion as used by TICA to hotels is more suitable than to convention centers. The result of this aspect showed that TICA had understood the characteristic of sales promotion. The last one is advertising. Both hotels and convention centers gave this aspect a low ranking. As a marketing tool, in general, advertising spent more money than any other tool and this wasn't the most effective way to contact the target markets. The characteristic of the convention industry decided that the advertising mix of TICA did not satisfy the convention providers.

\section{In place aspect}

Hotels had a more positive perception on distribution than convention centers. Hotels ranked the distribution aspect in the first order, which means hotels were satisfied with the distribution aspect of TICA. The reason for the difference of the ranking between hotels and convention centers was the different channels contacting the target markets between hotels and convention centers. Large hotels usually use electronic distribution such as the CRS (computer reservation system) as their main distribution mode. So convention hotels relied on electronic distribution more than convention centers.

\subsection{Recommendations}

The meeting and convention industry is perceived as a red-hot industry, and one of the most oriented sectors within the tourism industry. As many international conferences were held in Thailand the local meetings/conferences grew continuously. The role of Thailand CVB, say, TICA as the primary destination marketing organization became more and more important. The key findings in this research concluded that significant differences were observed in the providers' perception towards product, price, promotion and place dimensions of the marketing mix of TICA.

\subsubsection{Recommendation for product aspects}

CVBs don't produce products by themselves but they represent the convention providers to introduce the convention products for the target market. The foundation of effective marketing for CVB is knowing its product or service, knowing it well and approaching it from the correct perspective. A correct perspective involves a clear understanding of the product or service features and the resulting customer benefits. This in turn involves customer segmentation on the basis of benefits, which many marketing experts feel is the best and most effective manner in which o segment the market (Morrison 1998). This form of market segmentation is considered effective because customers do not necessarily buy the facility or the service; they buy the benefits they receive from the service or facility. One of the first activities a CVB marketer must complete is to put together a comprehensive feature and benefit profile for their destination. This should be done once the marketer has decided which convention industry segments to target. Then, in the light of relevant customer research the marketer can effectively position and promote their facility and service in a manner that satisfies those needs. The focus should always be on marketing the benefits and not the facility itself. So, first, they should have a full understanding of the convention market, the provision of the standards and quality of accommodation, facilities, and services to meet the convention traveler's requirements, and facilities attractive to the convention travelers. They should identify strengths and weakness in the current product mix about their image or attractions, their facilities, accommodation supply etc, and their accessibility.

Next, once the CVB has chosen to target one or more of the particular segments, it must then position their product accordingly. Product positioning involves the development of an appropriate marketing orientation, or service and marketing mix, to occupy a specific place in the mind of the 
customers within the market segments targeted (Morrison 1998). Positioning involves communicating the product or service benefits that meet the needs of the particular target.

Thirdly, product positioning is tied closely with product differentiation. The CVB should strive not only to meet the needs of select target market segments, but also to appear "different" from their competitors in positioning strategies. Additionally, the different convention tourists and different convention providers have different needs and wants, this study could, therefore, help CVB to adjust their management and marketing according to the different needs and wants.

\subsubsection{Recommendation for price aspects}

Product and price decisions are inseparable because of the importance that buyers place on price in relation to value. The buyer uses price to estimate value received even when competitive prices are the same. This means that there is a real opportunity to enhance the product's acceptance with the proper pricing decision. If the customer won't pay the price, it makes little matter how high or low the costs are or what the profit goals are. Price, like product, flows from the consumer, the integration of product and price is critical. Sometimes CVB has to work with the product they represent and set a price mix accordingly. In other words, rather than set a price mix for the target market, CVB may have to find the target market that will accept a given product at a given price.

CVBs don't decide the price, but they should have an understanding of the following questions. For example, can it satisfy the demand that would arise? Has it sufficient forward reservation of rooms and transport seats? Should or could prices be lowered when demand exceeds supply? Is it the destination's purpose to compete on price, quality or some unique aspect of a package? Are convention tourists sensitive to prices and frequent price changes? Are there any political implications? Having a good understanding about the aforesaid questions can help CVBs focus on the target market when they promote a destination.

The marketers should not forget that the price mixes vary at different stages of the product life cycle, e.g., pioneering stage, growth stage, maturity stage and the declining stage. While adopting a particular strategy, the marketers have a number of alternatives, such as, to lead the field by keeping prices down, to adopt a strategy of niche marketing by differentiating the product from the market leaders to select a particular segment and to select a particular segment to which the marketers aim their appeal.

However, CVBs can become a voice for their members when government action impacts on the price competitiveness of the city. And they can control elements of pricing through regulation, advice and through partnership with the private sector. CVBs can provide guidelines by suggesting minimum prices to protect small suppliers from fierce competition and maximum prices to protect consumers from overcharging. CVB should formulate partnerships with principals and train them on the importance of maintaining a fairly standardized pricing structure and policy.

\subsubsection{Recommendation for promotional aspects}

Promotion aspects were the focus of the marketing mix of CVB. First, convention travel promotion should necessarily aim at different groups: the people traveling and the purchase decision makers. The "personal" element of their service can target the actual traveler through advertisements in business travel magazines; whilst the communication of the pricing and business benefit approaches should be directly through the company.

Second, collateral materials are produced for both promotional and informational purposes, although both functions may be served by a single piece of print. The promotional aspects, briefly, involves using color photographs and prose laden with adjectives to sell attractive images of the destination to potential customers. The informative aspect of collateral material might involve hotel lists, a directory of services available within the destination, and information on traveling to the destination. Collateral material should be developed for the specific market segment targeted. The production of a single brochure to satisfy all possible customer needs is not effective. Collateral material should highlight and promote the benefits of the product that are important to the specific customer segment. However, given this specific benefit positioning, it is also important for the marketer to realize the importance of the general "branding" identity of the product or facility. A brand is a name, symbol or image that identifies the product or services of the selling organization 
(Kotler et al. 1996). Such branding, or the use of a visually consistent logo, color combination and layout of the images, is important in eliciting product recognition.

Third, advertising should also target the specific market segment. In the convention industry, CVB should target the meeting and conference organizer or decision maker, with a particular communication message addressing perceived customer benefits. CVB also should understand the correct communication medium to use, and choose the right magazine through which to reach these important decision makers.

Next, publicity and public relations play a significant role in the marketing activities of many destination marketing organizations. Public relations are extensively used for most tourism destinations. Destination representatives at national level establish tourism offices in their major markets to distribute promotional material and information as well as through their embassies. In addition, CVB should use public relations to generate news stories, articles and publicity in order to develop the awareness of consumers and persuade them to purchase their products. They should undertake public relations activities to improve their image with the general public. They should put out press releases on a range of "good news stories" about the destination which they send to the media which they feel are used by their target markets. Public relations are also critical for the development and updating of the right image (Morgan \& Pritchard, 1998; Kotler et al., 1996; Middleton, 1992). More often, hosting a journalist or a celebrity in the destination can generate more interest than any other forms of promotion because consumers are more passive receivers than with advertising.

Fifth, direct marketing has becoming a widely used marketing tool since the 1990s. Direct marketing refers to a form of marketing where services or products are marketed from the producer to the consumer (decision maker) without an intermediate channel of distribution (Kotler et al. 1996). Direct marketing commonly takes the form of direct mail or telemarketing. Many cities use direct-mail to let tourists know of the new and distinct commodities at their destination. They are now becoming new areas of travel for meeting planners. Sending a targeted convention decision maker an unsolicited information kit or brochure highlighting the benefits of a product or service may be of value. Vogt term such a transaction a "passive" search on behalf of the convention decision maker or conference organizer. The research indicates that 38.7 percent of such passive direct mail pieces are viewed as being useful in the decision-making process.

The final part of the promotion involves the use of sales promotions. Sales promotion is another marketing activity where customers are given a short-term inducement to make more of an immediate purchase (Morrison 1998). Sale promotion can also be effectively used to stimulate trial purchases. In the convention industry, they are frequently used to bring in business during the off-periods. Sales promotion involves the development of creative ideas aimed at producing business, or creating a customer, in support of the total marketing effort. Sales promotion must be in tune with overall objectives and must complement other elements of the marketing mix. One of the most common forms of sales promotion in the convention industries is packaging - a bundling of any combination of travel, rooms, meals, sightseeing, and so forth in one all-inclusive price. These kinds of packages should be directed at specific market segments. Although sales promotion are short-term oriented they may succeed in the long term, that is, they may develop repeat business.

\subsubsection{Recommendation for distribution aspects}

Distribution or marketing channels are defined as sets of interdependent organizations involved in the process of making a product or service available for use or consumption. The ultimate objective of a distribution channel can be summarized as: delivering the right quality and quantity of a product, in the right place, at the right time, at the right cost, to the right customer. Distribution is emerging as a critical element of strategic management and as one of the few remaining sources of real competitive advantage. Apart from influencing costs, increasingly distribution channels also support and enable product differentiation by adding value to the product and by contributing to the total brand experience and projecting powerful images.

Convention travelers can be influenced indirectly by people who are responsible for arranging 
business meetings and conferences. These include corporate travel officers and administrative staff in organizations who choose the location of meetings, as well as services suppliers. For destinations to attract convention travelers they need to develop strong links with the local business and academic communities as well as with various types of associations. This will enable CVBs to appreciate the needs of convention travelers and to provide convenient and adequate products. Often local associations, chambers, businesses or academics need to be closely involved in order to attract and arrange meetings and conferences at the destination. Consequently, relationships with the meeting and conference organizers are important to attract and satisfy the convention markets.

First, the CVB marketing to the convention traveler must determine the best means of selling its product and services to the determined target market. The distribution strategy adopted must be effective in reaching the market and be full integrated with the other elements of the marketing mix. The main distribution tasks are to communicate information to the relevant people and to provide the necessary travel arrangements with easy purchase facilities. A key element is to identify the important people in the convention travel decision-making process. Once they have been identified and knowledge of their roles within the process developed the distribution strategy may be effectively directed to the correct people. It's especially important to target the different decision-makers according to the different requirements of different convention providers.

Second, the availability of information on the Internet and the emergence of electronic intermediaries revolutionized distribution and destination marketing. Electronic distribution offers opportunities for closer interaction and co-operation at the local level. Destination Management Systems will need to be developed in order to enable the networking of all local convention providers as well as a comprehensive and innovative interface between the destinations and their prospective and current clients (Buhalis, 1994, 1997). IT is an easy way for visitors to obtain information about different aspects of the area. A person could make a reservation or shop for souvenirs on the internet. Many of the sites may only provide the basic level of information (Russell, 1996). This can be telling things just about the hotel, convention center and attraction but not actually being able to interact with each site. CVB should start to tailor their web site to meeting planners (Russell, 1996). It will make it quicker and easier for the meeting planner to access the information and be able to bring more convention visitors into the area.

\section{References}

[1] Abbey, J.R. \& Link, C.K. (1994) The convention and meeting sector: Its operation and research needs. In J.R. Ritchie \& C.R. Goeldner (Edss), Travel, Tourism, and Hospitality Research (2 ${ }^{\text {nd }}$ ed.), New York: Wiley pp.273-284

[2] Buhalis, D. (1994) Information and telecommunications technologies as a strategic tool for small and medium tourism enterprises in the contemporary business environment. Tourism --the state of the art: The Strathclyde symposium (pp. 254-275).

[3] Buhalis, D. (1997) Information and telecommunication technology as a strategic tool for economic, social and environmental benefits enhancement of tourism at destination regions. Progress in Tourism and Hospitality Research, 3(1), pp.71-93.

[4] Churchill, G.A. (1998) Basic Marketing Research, $3^{\text {th }}$ Edition, The Dryden Press.

[5] Crouch, G. I., \& Ritchie, J. R. B. (1998) Convention site selection research: a review, conceptual model, and propositional framework. Journal of Convention and Exhibition Management, I(1), pp.49 - 69.

[6] Elman, L. G. (1998) The state of CVBs. The Meeting Professional, April, pp.28 - 44.

[7] Gartrell, R. B. (1998) Destination marketing for convention and visitor bureaus (2 ${ }^{\text {nd }}$ ed.). Dubuque, Iowa: Kendall/Hunt Publishing Company.

[8] Getz, D., Anderson, D., \& Sheehan, L. (1998) Roles, issues, and strategies for convention and visitor bureau in destination planning and product development: a survey of Canadian bureau. Tourism Management, 19(4), pp.331 - 340.

[9] Kotler, P. (1994) Marketing Management: Analysis, Planning, Implementation, and Control, $8^{\text {th }}$ edn, Prentice- Hall, Englewood Cliffs, NJ. 
[10] Kotler, P., Bowen, J., \& Makens, J. (1996) Marketing for hospitality and tourism. UK: Prentice-Hall.

[11] Mark S., Philip L. \& Adrian T. (2003) Research Methods for Business Students, Third Edition, the Pitman Publishing Imprint.

[12] Morgan, N., \& Pritchard, A. (1998) Tourism promotion and power: Creating images, creating identities. Chichester: Wiley.

[13] Morrison, A. M., Bruen.S.M., \& Anderson, D.J. (1998) Convention and visitor bureaus in the USA: A profile of bureaus, bureau executives, and budgets. Journal of Travel \& Tourism Marketing, 7 (1), pp.1 - 20.

[14] Robert D. Reid, \& David C. Bojanic, (2006) Hospitality marketing management, fourth edition

[15] Weber, K., \& Roehl, W.S.(2001) Service quality issues for convention and visitor bureaus. Journal of Convention \& Exhibition Management. 3 (1). Pp.1- 19. 